\title{
Monitoring dan Evaluasi Penyelenggaraan Relawan Guru Pendidikan Kristen dan Katolik BKGS Salatiga
}

\author{
Bambang Ismanto ${ }^{1}$ \\ Arief Sadjiarto \\ Dwi Iga Luhsasi \\ Lelahester Rina \\ Destri Sambara Sitorus \\ Pendidikan Ekonomi, Universitas Kristen Satya Wacana
}

\section{A R T I C L E I N F O}

Article history:

Received 19-04-2021

Revised 29-04-2021

Accepted 18-05-2021

Key words:

Evaluasi, Monitoring, Pendidikan Kristen

\begin{abstract}
A B S T R A C T
Primary schools lack Christian and Catholic teachers so there are volunteer teachers of the religious teaching staff. The volunteer has not enough education and teaching experiences. Therefore, provision is important both from a spiritual perspective, introduction to vision and mission, core values of BKGS, and as well as intellectually Christian and Catholic learning methods. The method that we used was to distribute the instrument to partner schools. The activity is carried out in several steps: Preparation, Implementation, Evaluation, and Reporting. The outcome and achievement are the performance of BKGS volunteers who are placed in schools, especially primary school in Salatiga, are classified good. This activity implies that teachers can improve learning strategies in schools through evaluations.
\end{abstract}

\section{A B S T R A K}

Sekolah Dasar masih sangat minim tenaga pengajar agama Kristen dan Katolik sehingga terdapat pengutusan relawan tenaga pengajar agama tersebut. Para relawan belum banyak pengalaman di dunia pendidikan, maka pembekalan menjadi penting baik dari sisi spiritual, pengenalan visi misi, core value BKGS, serta secara intelektual teknik pembelajaran Agama Kristen dan Katolik. Metode yang dilakukan yaitu penyebaran instrumen ke sekolahsekolah mitra. Kegiatan dilakukan dalam beberapa langkah yaitu Langkah Persiapan, Langkah Pelaksanaan, Langkah Evaluasi, Langkah Pelaporan. Luaran dan capaian dari kegiatan ini yaitu kinerja relawan BKGS yang ditempatkan pada sekolah-sekolah khususnya Sekolah Dasar di Salatiga yang tergolong baik. Implikasi dari kegiatan ini, guru dapat memperbaiki strategi pembelajaran di sekolah melalui evaluasi yang dilakukan.

\footnotetext{
${ }^{1}$ Corresponding Author: lelahester.rina@uksw.edu
} 


\section{PENDAHULUAN}

Pendidikan memiliki peran dalam membentuk kualitas sumber daya manusia dalam mengembangkan ilmu pengetahuan yang ada. Pendidikan sebagai investasi manusia selain investasi secara fisik. Semakin tinggi kualitas sumber daya manusia maka efisiensi dalam produktivitas suatu negara dapat berkembang pula (Megawati, 2020). Kualitas sumber daya manusia inilah yang menjadi dasar dalam menciptakan peluang besar kualitas pendidikan di Indonesia. Namun, masih banyak fenomena yang terjadi dalam bidang pendidikan khususnya sumber daya manusia yang dibutuhkan. Sumber daya manusia yang dimaksud adalah pendidik yang secara langsung memberikan pengalaman pembelajaran kepada peserta didik. Guru berkewajiban dalam mengembangkan dan mendidik kualifikasi akademik secara komprehensif dan berkelanjutan melalui pengetahuan dan teknologi.

Bidang pendidikan dalam pelaksanaanya di sekolah perlu dilakukan pengawasan dan perbaikan melalui pembinaan pedagogik guru. Kurangnya sumber daya manusia dalam jenjang pendidikan khususnya pendidikan dasar menjadi dasar lembaga organisasi masyarakat untuk membantu menyelesaikan fenomena ini. Proses pembelajaran dalam pengawasan yang dilakukan menjadi bagian yang tidak terpisahkan guna meningkatkan mutu pembelajaran dan mutu penyelenggaraan sekolah (Putra, Hawa, \& Safitri, 2020). Peran guru memberikan dampak dalam keberhasilan pembelajaran di sekolah bersama peserta didik dalam menjalankan tugasnya secara profesional guru, meskipun secara pelaksanaan terdapat kendala dan kurang sesuai harapan. Dengan demikian perlu diadakan monitoring dan evaluasi yang dilakukan oleh kinerja guru. Perdana (2020) menyatakan bahwa monitoring dan evaluasi adalah proses yang dilakukan secara terencana melalui pengumpulan informasi sesuai indikator yang telah ditetapkan mengenai kegiatan program atau kegiatan sekolah sehingga diperoleh tindakan koreksi dalam penyempurnaan kegiatan program selanjutnya. Sedangkan evaluasi sebagai proses penilaian kinerja guru guna meninjau kualitas untuk memberikan umpan balik bagi peningkatan kualitas kinerja atau kegiatan di sekolah.

Adapun tujuan dari adanya monitoring dan evaluasi adalah untuk memantau, menilai detail yang terukur sehingga dapat meminimalisir kesalahan yang tidak diharapkan lembaga pendidikan sekolah. Prinsip monitoring dan evaluasi bagi organisasi antara lain: monitoring mempunyai rencana yang jelas, memiliki struktur organisasi yang baik, bersifat fleksibel, mengarahkan penyimpangan dan kekeliruan, menjamin adanya penilaian, menggambarkan suasana organisasi dan bersifat ekonomis (Zubaidi, 2020). Sedangkan menurut monitoring dan evaluasi menghasilkan perbaikan instruksional, belajar dan kurikulum. Dengan demikian, evaluasi sebagai dasar dalam menilai keberhasilan suatu kegiatan pengajaran di sekolah, kendala yang dilalui serta kekeliruan yang tidak direncanakan oleh guru yang dimonitor maupun dievaluasi.

Badan Kerjasama Gereja-gereja Salatiga (BKGS) merupakan tempat bersekutu, kebersamaan di antara Gereja-gereja di Kota Salatiga, yang diakui oleh Pemerintah Kota Salatiga, Lembaga Agama-agama dan Gereja-gereja di Kota Salatiga. BKGS saat ini memiliki sebanyak 96 anggota gereja dari berbagai denominasi yang ada di kota Salatiga. Salah satu misi yang dimiliki BKGS yaitu mewujudkan keesaan dalam wadah 
Badan Kerjasama Gereja-gereja Salatiga yang disingkat BKGS, menjadi mitra/partner Lembaga/Badan lain yang satu arah dan satu tujuan demi kesejahteraan masyarakat ciptaan. Maka BKGS menyusun rencana dengan menyiapkan relawan Guru Pendidikan Agama Kristen/Katolik (Guru PAK), yang akan diupayakan dari gereja anggota BKGS. Relawan tersebut akan diutus untuk melayani dalam hal ini mengajar di sekolah-sekolah yang selama ini belum ada guru agama Kristen dan Katolik. Masalah yang muncul berikutnya adalah kebutuhan transportasi atau honor untuk para relawan. Gereja anggota BKGS diharapkan bisa berkontribusi dalam penyediaan honor dan fasilitas transport bagi para relawan.

Di sisi lain oleh karena para relawan belum banyak pengalaman di dunia pendidikan, maka pembekalan menjadi penting dan mendesak, baik dari sisi spiritual, pengenalan visi misi, core value BKGS, serta secara intelektual dalam arti materimateri serta teknik-teknik pembelajaran Agama Kristen dan Katolik. BKGS beberapa kali bekerjasama dengan Prodi Pendidikan Ekonomi FKIP UKSW Salatiga untuk penyelenggaraan pembekalan bagi para relawan. Pembekalan pernah dilakukan di Prodi Pendidikan Ekonomi FKIP UKSW.

Kehadiran relawan di sekolah-sekolah harus mampu menjadi berkat, harus memberikan dampak positif bahkan diharapkan mampu menjadi teladan bagi guruguru yang lain di sekolahnya. Upaya yang bisa dilakukan adalah dengan menyelenggarakan kegiatan Monitoring dan Evaluasi. Maksud dan tujuan dari program relawan guru Pendidikan Agama Kristen dan Katolik adalah untuk melihat peran para relawan dalam proses belajar mengajar di sekolah, perbaikan dan tindak lanjut dalam kemajuan pelayanan di Sekolah Dasar Salatiga. Sasaran yang dimaksud dalam monitoring dan evaluasi ini adalah guru-guru relawan Pendidikan Agama Kristen dan Katolik yang tersebar di tingkat sekolah dasar Salatiga.

\section{METODE PELAKSANAAN}

Pendekatan dalam kegiatan monitoring dan evaluasi relawan guru Pendidikan Agama Kristen dan Katolik (PAK) BKGS menggunakan pendekatan campuran kuantitatif dan kualitatif. Data kuantitatif merupakan merupakan skala pencapaian kompetensi guru relawan PAK, sedangkan data kualitatif adalah bentuk pernyataan dan refleksi Kepala Sekolah serta rekan guru dimana relawan guru PAK melakukan tugas pelayanan pembelajaran. Prosedur kerja dalam kegiatan monitoring dan evaluasi relawan guru PAK BKGS sebagai berikut:

1. Pembahasan program kerjasama monitoring dan evaluasi relawan guru PAK BKGS.

2. MoU monitoring dan evaluasi relawan guru PAK BKGS.

3. Menentukan variabel dan indikator kinerja relawan guru PAK BKGS.

4. Penyusunan instrumen penilaian kinerja.

5. Pelaksanaan monitoring dan evaluasi.

6. Analisis data yang telah dikumpulkan

7. Diskusi dan koordinasi hasil monitoring dan evaluasi

8. Penulisan laporan pengabdian

9. Pembahasan draft laporan pengabdian dengan BKGS

10. Penyerahan laporan pengabdian 
Langkah-langkah yang ditempuh dalam kegiatan Pengabdian Masyarakat ini adalah sebagai berikut:

1. Langkah Persiapan, terdiri dari:

a. Dalam langkah persiapan yang dilakukan adalah memberikan pembekalan bagi para relawan guru. Pembekalan yang diberikan yaitu pembekalan spiritual, pengenalan visi misi, core value BKGS, dan materi serta teknik pembelajaran.

b. Melakukan pengumpulan data sekolah-sekolah yang kekurangan guru PAK

2. Langkah Pelaksanaan

Mulai tanggal 1 Juli 2019 para relawan guru sudah tersebar di 26 Sekolah Dasar Negeri di Kota Salatiga. Para relawan guru melaksanakan tugas sesuai dengan sekolah tempat ditugaskan.

3. Tahap Evaluasi

Tahap evaluasi dilakukan pada akhir kegiatan untuk melihat pemenuhan kompetensi guru PAK dalam melaksanakan perencanaan, proses, dan evaluasi pembelajaran.

4. Tahap Pelaporan

Berisi penyusunan hasil dari kegiatan Monitoring dan Evaluasi Penyelenggaraan Relawan Guru Badan Kerjasama Gereja-gereja Salatiga.

\section{HASIL DAN PEMBAHASAN}

Kegiatan pengabdian kepada masyarakat sudah terlaksana dengan menghasilkan laporan monev relawan guru PAK yang ditempatkan pada Sekolah Dasar yang terdapat di Kota Salatiga. Relawan guru PAK adalah sebuah program yang dicanangkan oleh BKGS) sebagai salah satu upaya untuk mengatasi kekosongan guru agama Kristen dan Katolik yang terjadi di beberapa Sekolah Dasar di Kota Salatiga. Akibat tidak adanya guru agama Kristen dan Katolik menyebabkan tidak terlayaninya kebutuhan pengetahuan rohani siswa. Program ini juga sebagai salah satu bentuk pelayanan gereja dalam bidang pendidikan. Para relawan diutus oleh masing-masing gereja untuk membantu mengajar pada sekolah-sekolah yang kekosongan guru agama Kristen dan Katolik.

Terdapat 24 relawan guru yang ditempatkan pada 27 Sekolah Dasar di Kota Salatiga. Penilaian terhadap relawan dilakukan pada bulan Januari - Februari 2020 dengan menggunakan angket dan wawancara. Terdapat tiga orang narasumber yang terdiri dari kepala sekolah dan dua rekan sejawat guru untuk menilai kinerja relawan selama menjalankan tugas di sekolah tersebut. Angket yang diberikan terdiri dari 18 butir pertanyaan yang berisi mengenai kehadiran relawan di sekolah, bagaimana relasi relawan dengan rekan kerja di sekolah, bagaimana respon siswa terhadap kehadiran relawan, perilaku relawan serta kelengkapan administratifnya. Berikut disajikan data Monev kegiatan Pengabdian kepada masyarakat antara lain: 
Tabel 1. Kehadiran Relawan

\begin{tabular}{lcccccc}
\hline \multirow{1}{*}{ Pernyataan } & \multicolumn{3}{c}{ Kepala Sekolah } & \multicolumn{2}{c}{ Rekan Sejawat } \\
\cline { 2 - 6 } & Tertinggi & Terendah & Rata-rata & Tertinggi & Terendah & Rata-rata \\
\hline $\begin{array}{l}\text { Guru hadir di sekolah } \\
\text { tepat waktu }\end{array}$ & 2 & 2 & 2 & 2 & 2 & 2 \\
\hline $\begin{array}{l}\text { Guru pulang setelah } \\
\text { tugas selesai }\end{array}$ & 2 & 1 & 1,93 & 2 & 1 & 1,98 \\
\hline $\begin{array}{l}\text { Guru bekerja sesuai } \\
\text { jadwal yang ditetapkan }\end{array}$ & 2 & 1 & 1,97 & 2 & 2 & 2 \\
\hline $\begin{array}{l}\text { Bila terpaksa } \\
\text { berhalangan hadir guru } \\
\text { memberitahu atau ijin } \\
\text { kepada kepala sekolah }\end{array}$ & 2 & 2 & 2 & 2 & 1,95 \\
\hline
\end{tabular}

Tabel 2. Relasi dengan Rekan Kerja

\begin{tabular}{|c|c|c|c|c|c|c|}
\hline \multirow[t]{2}{*}{ Pernyataan } & \multicolumn{3}{|c|}{ Kepala Sekolah } & \multicolumn{3}{|c|}{ Rekan Sejawat } \\
\hline & Tertinggi & Terendah & Rerata & Tertinggi & Terendah & Rata-Rata \\
\hline $\begin{array}{l}\text { Guru membaur dengan } \\
\text { rekan kerja sesama } \\
\text { guru maupun karyawan } \\
\text { sekolah }\end{array}$ & 2 & 1 & 1,77 & 2 & 1 & 1,81 \\
\hline $\begin{array}{l}\text { Guru bersedia } \\
\text { membantu bila rekan } \\
\text { kerja membutuhkan } \\
\text { bantuan }\end{array}$ & 2 & 1 & 1,80 & 2 & 1 & 1,88 \\
\hline $\begin{array}{l}\text { Guru dapat } \\
\text { bekerjasama dengan } \\
\text { rekan kerja di sekolah }\end{array}$ & 2 & 1 & 1,90 & 2 & 1 & 1,86 \\
\hline
\end{tabular}

Tabel 3. Penerimaan Peserta Didik

\begin{tabular}{|c|c|c|c|c|c|c|}
\hline \multirow[t]{2}{*}{ Pernyataan } & \multicolumn{3}{|c|}{ Kepala Sekolah } & \multicolumn{3}{|c|}{ Rekan Sejawat } \\
\hline & Tertinggi & Terendah & Rerata & Tertinggi & Terendah & Rata-Rata \\
\hline $\begin{array}{l}\text { Guru diterima dengan } \\
\text { baik oleh peserta didik } \\
\text { yang kristiani maupun } \\
\text { non kristiani }\end{array}$ & 2 & 2 & 2 & 2 & 2 & 2 \\
\hline $\begin{array}{l}\text { Peserta didik kristiani } \\
\text { sukacita menerima } \\
\text { kehadiran guru relawan } \\
\text { di sekolah }\end{array}$ & 2 & 1 & 1,97 & 2 & 2 & 2 \\
\hline
\end{tabular}


Tabel 4. Perilaku Guru di Sekolah

\begin{tabular}{lcccccc}
\hline Pernyataan & \multicolumn{3}{c}{ Kepala Sekolah } & \multicolumn{3}{c}{ Rekan Sejawat } \\
\cline { 2 - 7 } & Tertinggi & Terendah & Rerata & Tertinggi & Terendah & Rata-Rata \\
$\begin{array}{l}\text { Guru } \\
\text { berperilaku baik } \\
\text { terhadap seluruh } \\
\text { warga sekolah }\end{array}$ & 2 & 2 & 2 & 2 & 2 & 2 \\
\hline $\begin{array}{l}\text { Guru berpakaian } \\
\text { rapi dan sopan }\end{array}$ & 2 & 2 & 2 & 2 & 2 & 2 \\
\hline $\begin{array}{l}\text { Guru } \\
\text { berkomunikasi } \\
\text { dengan santun } \\
\text { kepada seluruh } \\
\text { warga sekolah }\end{array}$ & 2 & 1 & 1,97 & 2 & 2 & 2 \\
\hline
\end{tabular}

Tabel 5. Kelengkapan Administrasi Pembelajaran

\begin{tabular}{lcccccc}
\hline \multicolumn{1}{c}{ Pernyataan } & \multicolumn{3}{c}{ Kepala Sekolah } & & & Rekan Sejawat \\
& \multicolumn{1}{c}{ Tertinggi } & Terendah & Rerata & Tertinggi & Terendah & Rerata \\
& 2 & 1 & 1,87 & 2 & 1 & 1,93 \\
\hline $\begin{array}{l}\text { Guru menyiapkan } \\
\text { perangkat } \\
\text { pembelajaran sebelum } \\
\text { melaksanakan tugas } \\
\text { pembelajaran }\end{array}$ & & & & & & \\
\hline $\begin{array}{l}\text { Guru mengajar sesuai } \\
\text { dengan perangkat } \\
\text { pembelajaran yang } \\
\text { disiapkan }\end{array}$ & 2 & 1 & 1,93 & 2 & 1 & 1,97 \\
\hline $\begin{array}{l}\text { Guru melaksanakan } \\
\text { penilaian sesuai dengan } \\
\text { ketentuan yang telah } \\
\text { diatur sekolah }\end{array}$ & 2 & 1 & 1,93 & 2 & 1 & 1,93 \\
\hline $\begin{array}{l}\text { Guru memiliki daftar } \\
\text { nilai sebagai dokumen } \\
\text { penilaian }\end{array}$ & 2 & 1 & 1,90 & 2 & 1 & 1,95 \\
\hline $\begin{array}{l}\text { Guru memiliki buku } \\
\text { jurnal harian sebagai } \\
\text { catatan kegiatan } \\
\text { pembelajaran yang } \\
\text { dilakukan }\end{array}$ & 2 & 1 & 1,80 & 2 & 1 & 1,83 \\
\hline $\begin{array}{l}\text { Guru memiliki daftar } \\
\text { hadir siswa/absensi }\end{array}$ & 2 & 1 & 1,90 & 2 & 1 & 1,98 \\
\hline
\end{tabular}

Mutu diartikan sebagai proses belajar mengajar, interaksi guru dengan guru, antara guru dengan kepala sekolah, dan antara komponen sekolah lain. Para ahli mengartikan mutu merupakan suatu faktor atau variabel yang terkait dengan lingkungan, kondisi, dan kultur tertentu (Zamroni, 2011). 
Mutu sendiri adalah penilaian subyektif dari pada costumer pendidikan yang ditentukan oleh persepsi terhadap produk atau jasa. Persepsi sendiri dapat berubah karena pengaruh beberapa hal seperti iklim, reputasi, pengalaman, relasi, dan koneksi (Hardjosodarmo, 2003). Untuk itu sebuah mutu diperoleh dari persepsi customer terhadap produk dan jasa kita. Sebuah institusi pendidikan dapat meningkatkan mutunya dilihat dari keunggulan produk dan layanan jasanya dengan mengacu pada proses pendidikan dan hasil pendidikan. Proses pendidikan tersebut adalah guru, dimana guru sebagai fasilitator atau pendidik yang melaksanakan pendidikan dimana objeknya adalah peserta didik. Sedangkan hasil pendidikan adalah lulusan yang berkualitas dan yang memiliki bakat serta keterampilan yang terserap dalam dunia kerja.

Membekali peserta didik agar cerdas secara intelektual pengetahuan dan sosial merupakan peran guru di sekolah. Maka guru sebagai pendidik memiliki peran besar terhadap siswa dan keberlangsungan kegiatan belajar mengajar. Hal ini sejalan dengan pendapat Uno (2006) bahwa guru harus menguasai keterampilan dalam mengajar agar dapat mengelola proses pembelajaran dengan baik yang berimplikasi pada peningkatan kualitas lulusan sekolah dan diharapkan dapat menyelesaikan berbagai permasalahan yang timbul dalam proses kegiatan belajar mengajar. Guru dapat mengoptimalkan perannya di kelas dengan menguasai keterampilan mengajar. Penguasaan keterampilan mengajar yang baik akan mempengaruhi tingkat keaktifan dan partisipasi siswa sehingga bisa dikatakan bahwa peran keterampilan memberikan penguatan penting dalam kegiatan belajar mengajar.

Peranan guru yang begitu besar dalam pendidikan menjadi salah satu faktor dalam menentukan tinggi rendahnya kualitas hasil belajar. Kemampuan profesionalisme, kinerja, motivasi kerja, kompetensi yang dimiliki sangat mempengaruhi guru untuk meningkatkan mutu pendidikan. Kedudukan guru yang strategis sebagai pelayan dalam dunia pendidikan harus dapat melakukan tugas utamanya yaitu mendidik siswa.

Menurut Sastrawan (2016), guru profesional akan tercermin dalam penampilan pelaksanaan tugas-tugas yang ditandai dengan keahlian baik dalam penguasaan materi maupun metode. Dengan keahliannya itu seorang guru mampu menunjukkan perannya dengan baik sebagai seorang guru. Di samping keahliannya itu, sosok guru yang profesional ditunjukkan melalui tanggung jawabnya dalam melaksanakan seluruh pengabdiannya dan tanggung jawabnya sebagai seorang guru kepada siswa, orang tua, masyarakat, bangsa, dan negara.

Profesionalisme guru memberikan keleluasaan peluang untuk perbaikan dan pengembangan diri yang memungkinkan guru dapat memberikan pelayanan sebaik mungkin dan memaksimalkan kompetensinya. Rudi (2014) menyatakan bahwa ciri profesionalisme guru dapat ditunjukan oleh lima sikap, yaitu: Keinginan untuk selalu menampilkan perilaku yang mendekati standar ideal; Meningkatkan dan memelihara citra profesi; Keinginan untuk senantiasa mengejar kesempatan pengembangan profesional yang dapat meningkatkan dan memperbaiki kualitas pengetahuan dan keterampilan; Mengejar kualitas dan cita-cita dalam profesi; Memiliki kebanggan terhadap profesinya

Menurut Surya (2005) guru merupakan komponen penting dalam proses pembelajaran. Dengan profesionalisme itu guru akan mampu memperbaiki proses 
pembelajaran, sehingga dapat dengan otomatis pula dapat meningkatkan mutu pendidikan. Sebab guru profesional tentunya akan memberikan seluruh kemampuannya untuk kepentingan kemajuan mutu pendidikan itu sendiri. Semakin profesional guru, maka semakin dapat memperbaiki proses pembelajaran, dan semakin meningkat kualitas pencapaian tujuan pembelajaran.

BKGS melihat bahwa peranan guru yang amat penting bagi terciptanya siswa yang berkualitas maka BKGS merasa perlu untuk melakukan penilaian terhadap para relawan guru PAK yang ditempatkan di beberapa sekolah di Kota Salatiga. Penilaian tersebut terdiri atas penilaian terhadap kehadiran/kedisiplinan guru, relasi dengan rekan kerja, bagaimana respon dan penerimaan siswa terhadap kehadiran relawan guru, bagaimana perilaku relawan guru, serta kelengkapan administrasi yang dibutuhkan dalam pembelajaran.

Penilaian kinerja relawan guru berdasarkan tabel yang telah dipaparkan di atas menunjukkan bahwa secara keseluruhan kinerja relawan sangat baik, hal ini terbukti dari rata-rata penilaian tiap indikator yang menunjukkan angka yang tinggi yaitu mendekati angka 2 (sering), bahkan untuk beberapa indikator mendapat rata-rata 2 (sering). Berikut ini akan dipaparkan masing-masing indikator penilaian relawan guru PAK.

Pada indikator pertama yaitu komponen kehadiran relawan, yaitu guru hadir di sekolah tepat waktu mendapat rata-rata 2, baik penilaian dari kepala sekolah maupun rekan sejawat. Hal ini menunjukkan bahwa seluruh relawan memiliki disiplin waktu yang tinggi dengan hadir tepat waktu di sekolah. Para relawan memiliki jadwal mengajar yang telah diberikan oleh pihak sekolah sehingga mereka memiliki jadwal yang sudah teratur. Berdasarkan penilaian rekan sejawat, para relawan ini selalu melaksanakan jadwal mengajar yang telah diberikan, hal ini dibuktikan oleh skor ratarata yang diperoleh yaitu 2. Berdasarkan wawancara yang dilakukan dengan kepala sekolah maupun rekan sejawat, jika dalam keadaan terpaksa para relawan tidak dapat hadir ke sekolah, para maka relawan akan selalu meminta izin kepada kepala sekolah terlebih dahulu. Secara keseluruhan, penilaian aspek kehadiran relawan menunjukkan hasil yang sangat baik. Ini artinya para relawan memiliki sudah memiliki kompetensi kehadiran yang sangat baik yang mana hal ini diperlukan oleh seorang guru.

Indikator kedua yaitu komponen relasi dengan rekan kerja. Di sekolah tempat para relawan bertugas berharap para relawan menyesuaikan diri dan dapat berbaur dengan semua elemen di sekolah, mulai dari sesama rekan guru, pimpinan, siswa, karyawan, dan para pekerja seperti satpam ataupun petugas kebersihan. Para relawan harus dapat menyesuaikan diri dengan lingkungan yang baru sehingga dapat tercipta keakraban dan kerjasama yang baik dengan semua elemen. Berdasarkan penilaian, relasi para relawan dengan rekan kerja di sekolah sudah baik. Hal ini terlihat dari diperolehnya skor rata-rata sebesar 1,77 dari kepala sekolah dan skor rata-rata sebesar 1,81 dari rekan sejawat untuk indikator relawan membaur dengan rekan kerja sesama guru maupun karyawan. Relawan juga bersedia untuk membantu rekan guru lainnya yang membutuhkan bantuan serta dapat bekerjasama dengan baik. Kemampuan beradaptasi yang baik telah ditunjukkan oleh para relawan, hal ini sangat penting dimiliki dan terus dikembangkan karena dengan begitu kehadiran para relawan akan diterima dengan baik oleh lingkungan sekolah. Kesediaan memberikan bantuan serta keramahan para relawan juga menunjukkan nilai-nilai kekristenan yang dapat menjadi 
contoh untuk banyak orang. Hasil wawancara dengan kepala sekolah diketahui bahwa para relawan bersikap sangat ramah, cepat menyesuaikan diri baik dengan rekan guru ataupun siswa, akrab dengan siswa baik siswa kristiani maupun non kristiani, bahkan juga tidak canggung untuk menjalin komunikasi dengan orang tua siswa. Secara keseluruhan, relawan memiliki relasi yang baik dengan rekan kerja. Hal ini menunjukkan bahwa relawan telah memiliki kompetensi sosial yang baik.

Indikator ketiga yaitu komponen penerimaan peserta didik. Kehadiran guru baru di sebuah sekolah tentu akan menimbulkan berbagai respon oleh peserta didik. Ada respon positif seperti guru diterima dengan baik dan siswa bersemangat dengan adanya guru baru, atau sebaliknya yaitu respon negatif seperti siswa menolak kehadiran guru dan tidak bersemangat saat kegiatan belajar dengan guru tersebut. Namun beda halnya dengan kehadiran para relawan guru PAK yang ditempatkan di beberapa Sekolah Dasar, para siswa menyambut dan menerima kehadiran relawan dengan sangat baik. Dari hasil angket yang menunjukkan bahwa relawan diterima oleh peserta didik kristiani maupun non kristiani. Skor yang diberikan oleh kepala sekolah maupun rekan guru yaitu rata-rata 2 (sangat baik). Bagi peserta didik kristiani, kehadiran para relawan ini menjadi sebuah sukacita tersendiri karena selama ini peserta didik kristiani tidak terlayani kebutuhan rohaninya. Hasil wawancara dengan kepala sekolah mereka mengharapkan bahwa program ini dapat terus berlanjut karena mereka merasakan sekali manfaat dari kehadiran guru relawan ini. Dapat disimpulkan bahwa kehadiran relawan membawa dampak positif dan kehadirannya diterima dengan baik oleh peserta didik.

Indikator keempat yaitu komponen perilaku guru di sekolah. Perilaku guru seperti sikap dalam berkomunikasi, dalam berpakaian dan berpenampilan menjadi salah satu hal yang penting untuk dinilai. Seorang guru harus mampu menunjukkan dan memberikan contoh bahwa ia adalah seorang pendidik yang baik dan hal itu dapat terlihat dari bagaimana ia bertutur kata, berperilaku, dan berpakaian yang menunjukkan identitasnya. Hal ini juga sering dianggap sebagai sebuah aturan sosial bahwa guru harus menjadi cerminan bagi siswanya. Berdasarkan penilaian angket terlihat bahwa para relawan sudah menunjukkan perilaku yang sangat baik dengan diperolehnya skor 2 (sangat baik) baik itu dari kepala sekolah maupun rekan kerja. Berdasarkan segi berpakaian para relawan juga mendapat skor 2 (sangat baik) dari kepala sekolah maupun rekan kerja. Berdasarkan gaya berkomunikasi kepada atasan ataupun dengan sesama rekan, terlihat bahwa para relawan sudah sangat baik. Hasil wawancara dengan kepala sekolah dan juga rekan guru bahwa relawan telah menunjukkan contoh yang baik sebagai seorang guru, apalagi ini adalah guru agama yang erat hubungannya dengan sikap dan perilaku. Dapat ditarik kesimpulan bahwa para relawan memiliki kompetensi yang sangat baik terkait perilaku di sekolah.

Indikator kelima yaitu komponen kelengkapan administrasi pembelajaran. Sebagai seorang guru, kelengkapan administrasi menjadi hal yang sangat penting. Guru harus mempersiapkan terlebih dahulu rencana pembelajaran sebelum memulai pembelajaran agar proses pembelajaran berjalan lancar dan tujuan pembelajaran dapat tercapai. Selain itu, perangkat pembelajaran berguna sebagai pedoman dalam melaksanakan kegiatan pembelajaran. Di Indonesia, seorang guru dituntut untuk memiliki berkas-berkas administrasi tersebut. Berdasarkan penilaian, relawan telah menyiapkan perangkat pembelajaran sebelum memulai pembelajaran, hal ini dapat 
dilihat dari rata-rata skor yang diperoleh yaitu sebesar 1,87 dari kepala sekolah dan 1,93 dari rekan sejawat. Guru juga telah melaksanakan kegiatan pembelajaran sesuai dengan perangkat yang telah dibuat. Perangkat-perangkat lainnya seperti daftar nilai, daftar hadir siswa, buku jurnal harian dan lain-lain juga telah dimiliki oleh relawan. Dapat ditarik kesimpulan bahwa secara keseluruhan para relawan telah memiliki kompetensi inti dengan sangat baik.

Penjabaran dari kelima indikator yang telah dipaparkan di atas dapat ditarik kesimpulan bahwa relawan guru Pendidikan Agama Kristen yang ditugaskan memiliki kinerja dan kompetensi yang sangat baik. Kehadiran para relawan telah mengisi kekosongan yang selama ini terjadi dan kehadirannya membawa dampak yang baik bagi sekolah. Hampir seluruh respon kepala sekolah dan rekan guru meminta agar program yang sangat baik ini dapat terus berlanjut.

\section{SIMPULAN}

Berdasarkan dari hasil kegiatan pengabdian masyarakat, dapat disimpulkan bahwa kinerja relawan BKGS yang ditempatkan pada sekolah-sekolah khususnya Sekolah Dasar di Salatiga tergolong baik. Dilihat dari lima indikator penilaian yang dinilai oleh Kepala Sekolah dan Rekan Guru, para relawan mendapatkan skor lebih besar dari 1 sampai dengan 2. Indikator pertama yaitu terkait dengan kehadiran relawan skor rata-rata mencapai nilai minimum 1,95 dan maksimum 2 pada setiap poin. Pada indikator kedua yaitu relasi dengan rekan kerja mendapat skor antara 1,81 - 1,88 pada setiap poin. Walaupun lebih rendah dari indikator yang lainnya, indikator ini masih tergolong dalam kategori baik. Selain itu dua indikator selanjutnya, penerimaan peserta didik dan perilaku relawan di sekolah, mendapatkan skor maksimal pada setiap poin yaitu 2. Indikator terakhir yaitu kelengkapan administrasi pembelajaran mendapat skor antara 1,83 - 1,98. Setiap indikator tersebut menunjukkan hasil yang sudah memuaskan dan perlu ditindaklanjuti untuk program relawan pengajar agama Katolik dan Kristen.

Guna memberikan dan mempertahankan pelayanan yang lebih baik, maka periode kedepannya program ini harus terus berlanjut. Khususnya pada hal relasi dengan rekan kerja masih ada beberapa poin yang perlu untuk ditingkatkan supaya pada periode selanjutnya mendapatkan nilai yang maksimal. Selain itu, pihak sekolah juga sangat terbantu dengan adanya program ini, sehingga mengharapkan program ini akan terus berjalan.

\section{DAFTAR PUSTAKA}

Hardjosodarmo, S. (2003). Total Quality Management. Yogyakarta: Andi Offset. Megawati, E. (2020). Pelatihan Metode Pembelajaran Bahasa Inggris bagi Para Relawan Pengajar. Jurnal SOLMA, 9(1), 01-13. https://doi.org/10.29405/solma.v9i1.3042

Perdana, A. L. (2020). Pelaksanaan Monitoring Dan Evaluasi (Monev) Terhadap Kinerja Guru Di SMAN 16 Gowa. Seminar Nasional \& Call For Paper HUBISINTEK, 44-52. Retrieved from https://repository.ar- 
raniry.ac.id/id/eprint/10071/1/PDF GABUNG UPLOAD.pdf

Putra, L. V, Hawa, A. M., \& Safitri, H. B. (2020). Supervisi Akademik Berbasis Monitoring Dan Evaluasi Bagi Pembinaan Pedagogik Guru. Jurnal Ilmu ..., 1(2), 43-49. Retrieved from https://jurnallp2m.umnaw.ac.id/index.php/JIP/article/view/572

Rudi. (2014). Peranan Profesionalisme Guru dalam Upaya Meningkatkan Mutu Pendidikan. Www.Infodiknas.Com. Retrieved from http://www.infodiknas.com/peranan-profesionalisme-guru-dalam-upayameningkatkan-mutu-pendidikan.html

Sastrawan, K. B. (2016). Profesionalisme Guru Dalam Upaya Meningkatkan Mutu Pembelajaran. Jurnal Penjaminan Mutu, 2(2), 65. https://doi.org/10.25078/jpm.v2i2.73

Surya, H. M. (2005). Kapita Selekta Pendidikan SD. Jakarta: Universitas Terbuka. Uno, B. H. (2006). Orientasi Baru Dalam Psikologi Pembelajaran. Jakarta: PT Bumi Aksara.

Zamroni. (2011). Dinamika Peningkatan Mutu. Yogyakarta: Gavin Kalam Utama.

Zubaidi, A. (2020). Supervisi, Monitoring, dan Evaluasi Pendidikan dalam Peningkatan Mutu Lembaga Formal dan Non-Formal di Pondok Pesantren Nurul Jadid Paiton Probolinggo. GUYUB: Journal of Community Engagement, 1(2), 143-156. https://doi.org/10.33650/guyub.v1i2.1501 


\section{LAMPIRAN}

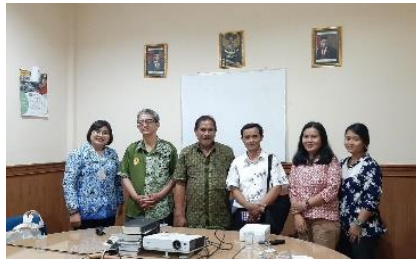

Rapat koordinasi Bersama pengurus BKGS

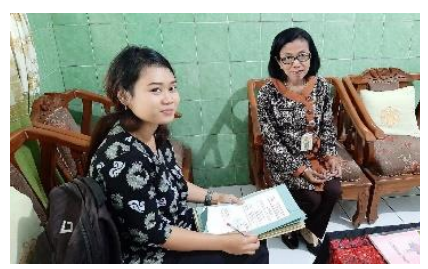

Kegiatan Monitoring dan Evaluasi di SDN 3

Tegalrejo

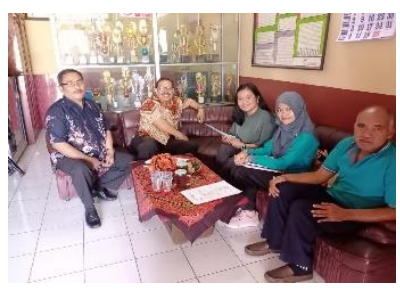

Kegiatan Monitoring dan Evaluasi di SDN 1

Noborejo

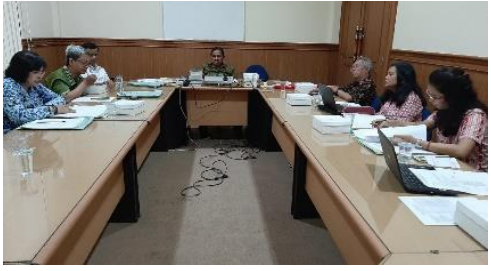

Rapat koordinasi Bersama pengurus BKGS

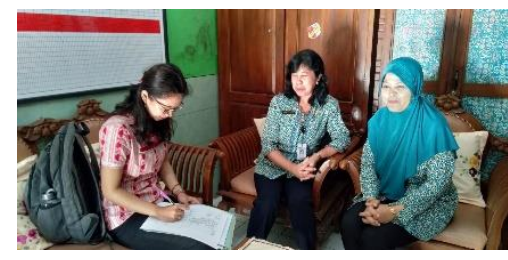

Kegiatan Monitoring dan Evaluasi di SDN 1-2 Tegalrejo

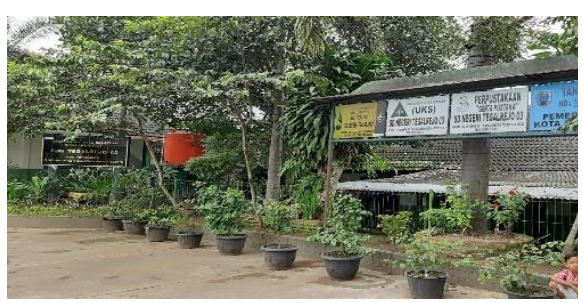

Lokasi SDN 3 Tegalrejo

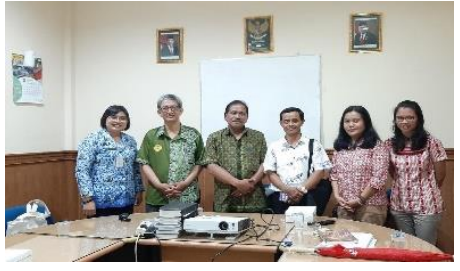

Rapat koordinasi Bersama pengurus BKGS

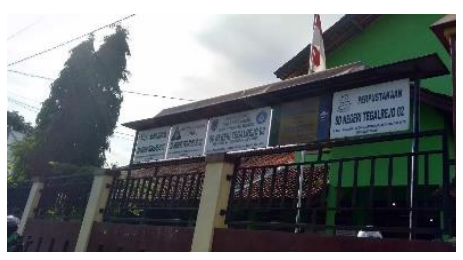

Lokasi SDN 2 Tegalrejo 